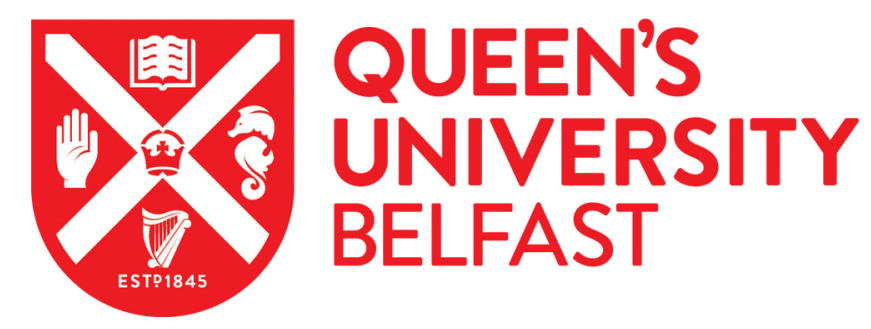

\title{
Delirium occurrence in hospitalised older people is positively associated with development of dementia postdischarge
}

Mitchell, G., \& Crooks, S. (2020). Delirium occurrence in hospitalised older people is positively associated with development of dementia postdischarge. Evidence-Based Nursing. https://doi.org/10.1136/ebnurs-2019-103227

\author{
Published in: \\ Evidence-Based Nursing
}

Document Version:

Peer reviewed version

Queen's University Belfast - Research Portal:

Link to publication record in Queen's University Belfast Research Portal

Publisher rights

Copyright ( 2020 BMJ Publishing Group Ltd.

This work is made available online in accordance with the publisher's policies. Please refer to any applicable terms of use of the publisher.

\section{General rights}

Copyright for the publications made accessible via the Queen's University Belfast Research Portal is retained by the author(s) and / or other copyright owners and it is a condition of accessing these publications that users recognise and abide by the legal requirements associated with these rights.

Take down policy

The Research Portal is Queen's institutional repository that provides access to Queen's research output. Every effort has been made to ensure that content in the Research Portal does not infringe any person's rights, or applicable UK laws. If you discover content in the Research Portal that you believe breaches copyright or violates any law, please contact openaccess@qub.ac.uk. 


\section{Delirium Occurrence in Hospitalised Older People is Positively Associated with Development of Dementia Post-Discharge}

Commentary on: Garcez FB, Apolinario D, Campora F et al. Delirium and post-discharge dementia: results from a cohort of older adults without baseline cognitive impairment. Age and Ageing, 2019; 48; 845-851.

\section{Commentary}

\section{Implications for Practice \& Research}

As many as one in three older people who experience delirium in a hospital setting may go on to develop dementia.

$>$ Delirium is associated with longer term cognitive impairment but there has been limited research or evidence about its impact on older people.

$>$ Future research on dementia prevention should consider delirium as a modifiable risk factor.

\section{Context}

Delirium is a disorder that is characterised by a rapid deterioration of mental function triggered by a medical disorder or environmental change ${ }^{1}$. Delirium has distressing effects and can lead to long-lasting physical and cognitive impairment ${ }^{2}$. It affects a person's behaviour, attention, thinking and memory ${ }^{12}$. It can also cause premature death ${ }^{3}$. Delirium more frequently occurs in people living with dementia and recent research has suggested that older people, with normal cognitive function, are also at risk of developing delirium ${ }^{4}$. The aim of this study was to investigate the association between delirium and post-discharge dementia in a cohort of older adults admitted to an acute older person's ward ${ }^{6}$.

\section{Methods}

The investigators undertook a retrospective cohort study examining acutely ill older people, aged 60 and over, in one 24-bed older persons ward in Sao Paulo, Brazil. The analysis took place between 2010 and 2016. Patients were excluded from this study if they were admitted for less than 48 hours or were receiving end-of-life care. Baseline cognitive assessment of older patients was recorded by a variety of validated tools including the Clinical Dementia Rating (CDR) and Informant Questionnaire on Cognitive Decline in the Elderly (IQCODE). The primary independent variable of this study was occurrence of delirium and this was detected using a short version of the Confusion Assessment Method. This was measured on admission and throughout the person's hospital stay. Incidence of post-discharge dementia, 
after a minimum of twelve months, was based on review of routine medical data by a suitable physician. The investigators used competing-risk proportional-hazard models to explore the association between delirium and post-discharge dementia.

\section{Findings}

In a six-and-a-half-year period there were 2,131 admissions to the ward and 309 patients were included in this study. The average age of participants was 78 years and $60 \%$ were female. Delirium was detected in 66 (21\%) patients. Older patients who experienced delirium had similar ages and comorbidities on admission compared to those without. After a 24-month follow-up, post-discharge dementia was confirmed in 59 (19\%) patients. Of these $32 \%$ had previously experienced delirium and $16 \%$ had not. After adjusting for potential confounding factors, delirium was associated with the development of post-discharge dementia, with age on admission being a major risk factor. Findings of the study show the link associated between delirium and post-discharge dementia was statistically significant $(\mathrm{p}<0.02)$.

\section{Commentary}

The results of this cohort study suggest that older people experiencing delirium at hospital are twice as likely to develop post-discharge dementia. In this study, one in three acutely ill older people who experienced delirium in the hospital, went on to develop post-discharge dementia. A key strength of this study was the consistency of delirium-screening throughout the patient's time in hospital and the post-discharge timeframe which was a median of 24 months. These statistically significant findings indicate that delirium is a key modifiable risk factor in the development of dementia and preventative care is paramount in older people's wards.

\section{References}

1.Dixon M, Assessment and Management of Older Patients with Delirium in Acute Settings. Nursing Standard, 2018; 30; 35-42.

2. Davis D, Kreisel S, Muniz Terrera G et al. The epidemiology of delirium: challenges and opportunities for population studies. American Journal Geriatric Psychiatry 2013;21:11731189.

3. Ospina J, King F, Madva E et al. Epidemiology, mechanisms, diagnosis and treatment of delirium: A narrative review. Clinical Medicine and Therapeutics, 2018; 1:3.

4. Lange P, Lamanna M, Watson $\mathrm{R}$, et al. Undiagnosed delirium is frequent and difficult to predict: Results from a prevalence survey of a tertiary hospital. Journal of Clinical Nursing, $2019 ; 28 ; 2537-2542$. 
5. Mitchell G. Undiagnosed delirium is common and difficult to predict among hospitalised patients. Evidence-Based Nursing; 2019; Published Online First: 11 July 2019. doi: 10.1136/ebnurs-2019-103120.

6. Garcez FB, Apolinario D, Campora F et al. Delirium and post-discharge dementia: results from a cohort of older adults without baseline cognitive impairment. Age and Ageing, 2019; $48 ; 845-851$.

\section{Commentator Details:}

Name: Dr Gary Mitchell ${ }^{A}$ \& Miss Sophie Crooks ${ }^{\mathrm{B}}$

Affiliation: ${ }^{\text {A }}$ Lecturer (Education), School of Nursing \& Midwifery, Queen's University

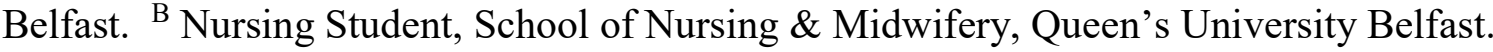

Correspondence Address: Queen's University Belfast, School of Nursing and Midwifery, Medical Biology Centre, 97 Lisburn Road, Belfast, Northern Ireland, BT9 7BL.

Email: Gary.Mitchell@qub.ac.uk

\section{Competing Interests:}

Nothing to declare. 